\title{
Metabolic substrates are not mobilized from the osmoregulatory organs (gills and kidney) of the estuarine pufferfishes Sphoeroides greeleyi and S. testudineus upon short-term salinity reduction
}

\author{
Viviane Prodocimo, Carine F. Souza, Cristina Pessini, Luiz Claudio Fernandes and \\ Carolina A. Freire
}

The marine-estuarine species of pufferfishes Sphoeroides testudineus and S. greeleyi are very efficient osmoregulators. However, they differ with respect to their tolerance of salinity reduction. During low tide $S$. testudineus remains in diluted estuarine waters, whereas $S$. greeleyi returns to seawater (SW). The hypothesis tested here was that the short-term mobilization of metabolic substrates stored in their main osmoregulatory organs would correlate with this differential tolerance. Fishes exposed to 5\%o (for $6 \mathrm{~h}$ ) were compared to those kept in 35\%. Branchial and renal contents of triglycerides, protein and glycogen were evaluated, and total ATPase activity accounted for the tissues' metabolism. Plasma osmolality, chloride and glucose, hematocrit, and muscle water content were also measured. Total triacylglycerol content was higher in S. greeleyi than in S. testudineus in both salinities and in both organs. Kidney glycogen contents were higher in S. greeleyi than in S. testudineus in 5 and $35 \%$. Total ATPase activity was reduced in 5\%o when compared to 35\% in the kidney of S. greeleyi, and was higher in the gills of $S$. greeleyi than in those of $S$. testudineus, in both salinities. Upon exposure to dilute SW, both species displayed a similar osmoregulatory pattern: plasma osmolality and chloride were reduced. Again in both species, stability in muscle water content indicated cellular water content control. Although the metabolic substrates stored in the osmoregulatory organs of both species were not mobilized during these short-term sea water dilution events, some differences could be revealed between the two species. S. greeleyi showed more metabolic reserves (essentially triacylglycerols) in these organs, and its gills showed higher total ATPase activity than those $S$. testudineus.

Os baiacus marinhos Sphoeroides testudineus e S. greeleyi são freqüentadores de estuários e eficientes osmorreguladores. No entanto, eles diferem quanto à sua capacidade de tolerar a redução de salinidade. Durante a descida de maré S. testudineus permanece no estuário com salinidade reduzida e $S$. greeleyi retorna para a água do mar. A hipótese testada neste estudo foi a de que a mobilização em curto prazo dos substatos metabólicos armazenados nos órgãos osmorregulatórios poderia explicar esta tolerância diferencial a redução de salinidade. Peixes expostos a 5\%o (por $6 \mathrm{~h}$ ) foram comparados com os mantidos em $35 \%$. O conteúdo branquial e renal de triacilglicerol, proteína e glicogênio foram avaliados, e a atividade ATPásica total foi quantificada para representar o metabolismo do tecido. Osmolalidade, cloreto e glicose plasmáticos, o hematócrito e o conteúdo de água no músculo também foram mensurados. O conteúdo total de triacilglicerol foi maior em $S$. greeleyi do que em $S$. testudineus em ambas as salinidades e em ambos os órgãos. O conteúdo renal de glicogênio foi maior em $S$. greeleyi quando comparado a S. testudineus na duas salinidades. A atividade ATPásica total foi reduzida em 5\% quando comparada a 35\% no rim de $S$. greeleyi, e foi maior nas brânquias de $S$. greeleyi quando comparada aos valores para $S$. testudineus em ambas as salinidades. Após a exposição a água do mar diluída, ambas as espécies apresentaram padrão osmorregulatório similar: osmolalidade e cloreto plasmáticos foram reduzidos. Em ambas as espécies a estabilidade do conteúdo de água no músculo indicou capacidade de regular o conteúdo de água intracelular. Os substratos metabólicos estocados nos órgãos osmorregulatórios de ambas as espécies não foram mobilizados durante a exposição de curto-prazo a diluição da água do mar, porém algumas diferenças foram reveladas entre as duas espécies. S. greeleyi apresentou maior reserva metabólica (essencialmente triacilglicerol) em seus órgãos, e suas brânquias apresentaram maior atividade ATPásica total quando comparado a S. testudineus.

Key words: Fish gill, Fish kidney, Glycogen, Metabolism, Osmoregulation, Tetraodontidae.

Departamento de Fisiologia, Setor de Ciências Biológicas, Universidade Federal do Paraná, Centro Politécnico, 81531-990 Curitiba, Paraná, Brazil.vprodocimo@ufpr.br 


\section{Introduction}

Marine teleosts are hypo-osmotic to seawater. Their gills act to maintain plasma homeostasis by secreting the excess of salt taken up as they drink seawater (Jobling, 1995; Evans et al., 1999, 2005). The kidney is not as relevant as are the gills for osmotic and ionic regulation because renal tubules essentially secrete multivalent ions $\left(\mathrm{Mg}^{+2}\right.$ and $\left.\mathrm{SO}_{4}^{-2}\right)$ (Beyenbach \& Baustian, 1989; Beyenbach et al., 1993; Hentschel \& Zierold, 1994; Jobling, 1995). Estuarine teleosts, while facing fast salinity changes, maintain the homeostasis of their extracellular fluid activating energy-consuming osmoregulatory mechanisms (mainly in the gills) in order to switch from salt secretion to salt absorption mechanisms or vice-versa (Mancera \& McCormick, 2000; Prodocimo \& Freire, 2001; 2004; Scott et al., 2004; Evans et al., 2005; Sangiao-Alvarellos et al., 2005; Prodocimo et al., 2007). Vectorial salt transport against electrochemical gradients is ultimately ATP-driven (e.g., Stahl \& Baskin, 1990; Evans et al., 2005). In fact, the major ATPase involved with the energization of salt transport in gills of euryhaline fishes is the $\mathrm{Na}, \mathrm{K}$-ATPase (reviewed in Evans et al., 1999, 2005). In the osmoregulatory organs, the $\mathrm{Na}, \mathrm{K}$-ATPase is the major contributor to total ATPase activity (Venturini et al., 1992). Thus, in those organs, ATPase activity changes can indeed at least partially represent changes in the organs' energy budget, and can be related to the Na,K-ATPase activity, in fishes submitted to osmotic stress (Perry \& Walsh, 1989; Venturini et al., 1992; Díaz et al., 1998). Both hyporegulation in high salinity and hyper-regulation in low salinity demand energy consumption, for gradient maintenance. Although fish metabolism measured by oxygen consumption as a function of salinity displays a variable response, it is often reported as an "U-shaped" curve: higher metabolism in very low (frequently fresh water) or high salinities (often hypersaline), versus lower metabolism in intermediary, more isosmotic salinities (e.g., Jensen et al., 1998; Kelly et al., 1999; Imsland et al., 2003; Laiz-Carrión et al., 2005).

The energy requirement of the gills and kidney is partially maintained by using the metabolic substrates stored in these organs (Tseng et al., 2007). However, there is scant information about the mobilization of their metabolic substrates according to the salinity of acclimation in fish (Hansen et al., 1999; Laiz-Carrión et al., 2002, 2005; Sangiao-Alvarellos et al., 2003, 2005). Still, metabolic changes in branchial and renal tissues have been essentially associated to long periods (days) of exposure to different salinities (Hansen et al., 1999; Laiz-Carrión et al., 2005; Sangiao-Alvarellos et al., 2003, 2005). The liver has been the major focus of studies on metabolism versus salinity (Woo \& Fung, 1981; Woo \& Wu, 1982; Nakano et al., 1998). It is proposed that the liver is the main site of glycogen storage and it provides plasma with glucose, which is then taken up for energy generation in the gills (e.g., Vijayan et al., 1996; Sangiao-Alvarellos et al., 2005). However, marine teleosts such as the sea bream Chrysophrys major (Woo \& Fung, 1981), the red grouper (Epinephelus akaara), and also the black sea bream (Mylio macrocephalus) (Woo \& Wu, 1982) presented no changes in their hepatic glycogen content and protein after long periods (10-14 days) of exposure to dilute seawater $(\sim 5 \%)$.

The effects of short-term (hours) salinity changes on metabolic reserves of fish have been poorly investigated (Woo \& Wu, 1982; Nakano et al., 1998; Tseng et al., 2007). In the freshwater euryhaline tilapia (Oreochromis mossambicus) liver glycogen content increased after 6 hours in $23 \%$ (Nakano et al., 1998), but rapid mobilization of the local reserves of branchial glycogen has been observed to fuel ion transport mechanisms in ionocytes of the gills of tilapia upon short-term (3 hours) increase in salinity (25\%o) (Tseng et al., 2007). In the marine teleosts red grouper (Epinephelus akaara) and black sea bream (Mylio macrocephalus), shortterm (6 hours) exposure to 7\%o salinity (from 30\%o) did not induce consumption of liver glycogen content (Woo \& Wu, 1982). We are not aware of any study using marine/estuarine teleosts in a short-term protocol of salinity reduction with further evaluation of branchial and renal metabolic substrate store, in a protocol somewhat related to their natural habitat.

The pufferfish Sphoeroides testudineus (Linnaeus, 1758) is an abundant teleost in bays and estuaries along the Brazilian coast, in places with salinities ranging from 34\% to $0 \%$ (Figueiredo \& Menezes, 2000). Sphoeroides greeleyi Gilbert, 1900 is also common along the Brazilian coast, but is found in areas of higher salinity (Figueiredo \& Menezes, 2000; Vendel et al., 2002), and has been observed to be more sensitive to salinity reduction either in the laboratory (Prodocimo $\&$ Freire, 2001) or in the field (Prodocimo \& Freire, 2004), when compared to $S$. testudineus. The hypothesis tested here was that the two species of pufferfishes, with distinct tolerances of seawater dilution, might differ in their short-term use of metabolic substrates stored in their main osmoregulatory organs, when challenged with salinity alteration. The disturbance in the osmotic homeostasis of these fish would impose a metabolic demand of the energetic substrates stored in their osmoregulatory organs, thus potentially more readily available (Tseng et al., 2007). This hypothesis is supported by previous reports that rapid alterations in transport mechanisms (including changes in $\mathrm{Na}^{+}, \mathrm{K}^{+}$-ATPase activity) ensue when estuarine fishes endure salinity changes in their environment (Mancera \& McCormick, 2000; Sakamoto et al., 2000; Marshall, 2003; Wood \& Laurent, 2003; Prodocimo et al., 2007).

\section{Material and Methods}

Adults, male or female of $S$. testudineus $(\sim 15 \mathrm{~cm}$ body length, $40 \mathrm{~g}$ body mass, deposited at the Museum of Natural History Capão da Imbuia, Curitiba, MHNCI 11700) and $S$. greeleyi ( $10 \mathrm{~cm}, \sim 20 \mathrm{~g}$, MHNCI 11701) were obtained from Baguaçu river tidal creek (25³3'06.33' $\left.\mathrm{S}, 48^{\circ} 23^{\prime} 41.63^{\prime \prime} \mathrm{W}\right)$, at the south margin of Paranaguá Bay, State of Paraná, Brazil, in May and August, 2003, May and June 2004, June 2006, and finally in February, 2007. Fish were obtained during flow tide using a fyke type net installed across the creek channel. The net has remained in place for 6 hours, until the high tide peak, 
when the net was retrieved and the animals were transferred to plastic gallons with aerated water from the collection site. Water salinity was verified (29-30\%o) immediately after fishing the animals. Fishes were then transferred to the laboratory, where they were acclimated for $\sim 7$ days in a $160 \mathrm{~L}$ tank with $30 \%$, temperature of $21 \pm 1^{\circ} \mathrm{C}$, constant aeration and biological filtration, under natural photoperiod. Fish were daily fed $a d$ libitum with fresh prawns and earthworms.

Sphoeroides testudineus and S. greeleyi were exposed for 6 hours to full-strength seawater 35\% or to diluted seawater 5\%. Experiments were performed in 30-liter aquaria with constant aeration and temperature of $21 \pm 1^{\circ} \mathrm{C}$, and a maximum number of 3 fish per experimental aquarium. Seawater 35\%o was prepared appropriately by mixing $30 \%$ seawater with the first thaw of frozen seawater. Experimental fishes submitted to $35 \%$ were directly transferred from the stock tank of $30 \%$ to the experimental aquarium 35\%. Seawater was diluted with filtered dechlorinated tap water from $\sim 30 \%$ o down to $\sim 10-12 \%$ o along 4 hours (flux of $0.7 \mathrm{ml} / \mathrm{seg}$ ) to avoid osmotic shock to fishes exposed to 5\%. The fish then remained 10-12 hours in salinity $10-12 \%$ overnight, and were then transferred to $5 \%$, where they remained for 6 hours. Those fish submitted to salinity reduction had this protocol of transfer because of the large difference in salinity.

Fishes were then anaesthesized with benzocaine (in ethanol, $80 \mathrm{mg} / \mathrm{l}$ of aquarium water), were opened by ventral incision, and a blood sample was withdrawn through cardiac puncture using an heparinized insulin syringe. Blood samples were centrifuged for $10 \mathrm{~min}(2100 \times \mathrm{g})$ and plasma was immediately frozen at $-20^{\circ} \mathrm{C}$. Blood was also collected into glass capillaries for immediate hematocrit reading. All gill arches and the whole kidney were removed for the assays of total ATPase activity, triacylglycerol and glycogen contents, and total protein concentration. A dorsal axial muscle sample $(\sim 0.40 \mathrm{~g})$ was removed for tissue water content determination. These procedures have been approved by the Committee on Ethics in Animal Experimentation (CEEA) of the Institute of Biological Sciences of the Universidade Federal do Paraná (UFPR), certificate number 072, issued on May 3rd, 2004.

Plasma osmolality (vapor pressure micro-osmometer Vapro 5520, Wescor, USA), chloride (commercial kit, Labtest, Brazil), and glucose (commercial glucose oxidase kit, Laborclin, Brazil) were assayed in thawed samples. Hematocrit was determined after 12,000 rpm centrifugation (10 min, Presvac centrifuge, Argentina). For muscle water content determination, muscle samples were weighed on an analytical balance, dried at $100^{\circ} \mathrm{C}$ for $24 \mathrm{~h}$, then weighed again, and total water content was expressed as a percentage of the wet mass.

Gills and kidneys were homogenized (Potter-S, in ice) in

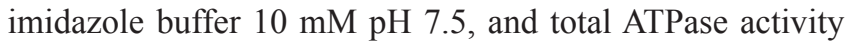
was quantified in the supernatant $(1000 \mathrm{xg}, 10 \mathrm{~min})$ as the appearance of inorganic phosphate (Fiske \& Subbarow, 1925), using Tris-ATP $3 \mathrm{mM}$ as substrate, at $20^{\circ} \mathrm{C}$, as described in detail previously (Freire et al., 1995; Romão et al., 2001). These same samples had their total protein and triacylglycerol content assayed, using commercially available kits (Labtest,
Brazil). Proteins were read according to the Biuret method, and triacylglycerols using an enzymatic method: lipoprotein lipase, glycerol kinase, glycerol-3-phosphate oxidase, and peroxidase. Tissue glycogen content was determined as routinely in the literature, according to Keppler \& Decker (1984), using approximately $0.07 \mathrm{~g}$ of gills or kidneys. Total protein concentration of these tissue samples was measured according to Bradford (1976).

Two-way ANOVA was performed to identify the effect of salinity (5\%o and $35 \%$ ) or species (S. testudineus and $S$. greeleyi), on all parameters, followed by Tukey post hoc test. Statistical significance was indicate by $\mathrm{p}<0.05$.

\section{Results}

Plasma osmolality and chloride levels in fishes of both species were lower in 5\% than in 35\%. On the contrary, the hematocrit of both species was higher in 5\% than in fishes exposed to $35 \%$. Further, the hematocrit of $S$. greeleyi was higher than that of $S$. testudineus in both salinities. Muscle water content and plasma glucose of $S$. testudineus and $S$. greeleyi were both unaffected by salinity reduction $(5 \%$ ) (Table 1$)$.

Table 1. Plasma osmolality (mOsm. $\left.\mathrm{kgH}_{2} \mathrm{O}^{-1}\right)$, chloride (mM), plasma glucose $\left(\mathrm{mg}^{\mathrm{dL}} \mathrm{L}^{-1}\right)$, hematocrit $(\%)$, and muscle water content (\%) of Sphoeroides testudineus and S. greeleyi after short-term exposure to seawater of $5 \%$ or $35 \%$ salinity, mean \pm standard error. $*=$ salinity effect $(5 \% \neq \neq 35 \% 0), \mathrm{p}<0.05 ; \&=$ species effect $(S$. testudineus $\neq S$. greeleyi), $\mathrm{p}<0.05$.

\begin{tabular}{|c|c|c|c|}
\hline & Salinity & S. testudineus & S. greeleyi \\
\hline \multirow{2}{*}{ Plasma Osmolality } & $5 \%$ & $\begin{array}{c}308.5 \pm 2.4 \\
(n=11)^{*}\end{array}$ & $\begin{array}{c}304.6 \pm 7.1 \\
(n=11)^{*}\end{array}$ \\
\hline & $35 \%$ & $\begin{array}{c}343.0 \pm 9.4 \\
(n=11)\end{array}$ & $\begin{array}{c}341.7 \pm 4.0 \\
(\mathrm{n}=11)\end{array}$ \\
\hline \multirow{2}{*}{ Plasma Chloride } & $5 \%$ & $\begin{array}{c}144.3 \pm 2.5 \\
(n=11)^{*}\end{array}$ & $\begin{array}{c}148.9 \pm 5.1 \\
(\mathrm{n}=11)^{*}\end{array}$ \\
\hline & $35 \%$ & $\begin{array}{c}155.2 \pm 2.9 \\
(\mathrm{n}=11)\end{array}$ & $\begin{array}{c}161.6 \pm 2.4 \\
(\mathrm{n}=11)\end{array}$ \\
\hline \multirow{2}{*}{ Hematocrit } & $5 \%$ & $\begin{array}{c}27.9 \pm 1.1 \\
(\mathrm{n}=9)^{*}\end{array}$ & $\begin{array}{l}30.5 \pm 1.2 \\
(n=11)^{* \&}\end{array}$ \\
\hline & $35 \%$ & $\begin{array}{c}25.7 \pm 1.1 \\
(n=11)\end{array}$ & $\begin{array}{c}27.4 \pm 1.2 \\
(n=11)^{\&}\end{array}$ \\
\hline \multirow{2}{*}{$\begin{array}{l}\text { Muscle Water } \\
\text { Content }\end{array}$} & $5 \%$ & $\begin{array}{c}80.7 \pm 2.0 \\
(n=6)\end{array}$ & $\begin{array}{c}81.0 \pm 0.3 \\
(n=11)\end{array}$ \\
\hline & $35 \%$ & $\begin{array}{c}82.7 \pm 0.9 \\
(n=6)\end{array}$ & $\begin{array}{c}81.3 \pm 0.8 \\
(n=11)\end{array}$ \\
\hline \multirow{2}{*}{ Plasma Glucose } & $5 \%$ & $\begin{array}{c}22.9 \pm 2.8 \\
(n=11)\end{array}$ & $\begin{array}{c}19.0 \pm 1.7 \\
(n=6)\end{array}$ \\
\hline & $35 \%$ & $\begin{array}{c}24.8 \pm 2.9 \\
(n=13)\end{array}$ & $\begin{array}{c}23.7 \pm 2.9 \\
(n=5)\end{array}$ \\
\hline
\end{tabular}

Branchial total ATPase activity (Table 2) in both species did not change upon salinity reduction $(\mathrm{p}>0.05)$. Renal total ATPase activity (Table 2) in $S$. greeleyi decreased upon exposure to dilute seawater $(\mathrm{p}<0.05)$ and the activity in seawater 
of $35 \%$ was higher in the kidney of S. greeleyi than in that of $S$. testudineus $(\mathrm{p}<0.05)$. Glycogen content of gills and kidney of both species was not modified after exposure to $5 \%$ (Table $2)$. Kidney glycogen content in the $S$. greeleyi was higher when compared to $S$. testudineus, in both salinities $(\mathrm{p}<0.05)$. $S$. greeleyi presented higher levels ( twofold) of triacylglycerol (Table 2) both in branchial and renal tissue, and in both salinities, than its congener $S$. testudineus $(\mathrm{p}<0.05)$. Finally, total protein concentration of both tissues and in both species was not affected by salinity reduction (Table 2 ).

Table 2. Total ATPase activity ( $\left.\mu \mathrm{molPi} \cdot \mathrm{mgProt} / \mathrm{h}^{-1}\right)$, triacylglycerol (mg.Triac/mg.Prot) and glycogen content ( $\mu \mathrm{mol}$ glycosyl units $/ \mathrm{g}$ ), and protein concentration $(\mathrm{mg} / \mathrm{mL}$ ) of branchial and renal tissues of $S$. testudineus and $S$. greeleyi after short-term exposure to seawater of 5\%o or 35\% salinity, mean \pm standard error. $*=$ salinity effect $(5 \% 0 \neq 35 \%), \mathrm{p}<0.05 ; \&=$ species effect $(S$. greeleyi $\neq S$. testudineus $), \mathrm{p}<0.05$.

\begin{tabular}{|c|c|c|c|c|c|}
\hline & \multicolumn{3}{|c|}{ Gill } & \multicolumn{2}{|c|}{ Kidney } \\
\hline & Salinity & S. testudineus & S. greeleyi & S. testudineus & S. greeleyi \\
\hline \multirow{2}{*}{$\begin{array}{l}\text { Total ATPase } \\
\text { activity }\end{array}$} & $5 \%$ & $\begin{array}{c}1.2 \pm 0.1 \\
(\mathrm{n}=8)\end{array}$ & $\begin{array}{l}1.7 \pm 0.2 \\
(\mathrm{n}=8)^{\&}\end{array}$ & $\begin{array}{c}1.7 \pm 0.2 \\
(\mathrm{n}=7)\end{array}$ & $\begin{array}{l}1.4 \pm 0.2 \\
(\mathrm{n}=8)^{*}\end{array}$ \\
\hline & $35 \%$ & $\begin{array}{c}1.3 \pm 0.04 \\
(\mathrm{n}=7)\end{array}$ & $\begin{array}{l}1.7 \pm 0.1 \\
(\mathrm{n}=7)^{\&}\end{array}$ & $\begin{array}{c}1.4 \pm 0.2 \\
(\mathrm{n}=9)\end{array}$ & $\begin{array}{c}2.1 \pm 0.3 \\
(\mathrm{n}=8)^{\&}\end{array}$ \\
\hline \multirow{2}{*}{$\begin{array}{l}\text { Glycogen } \\
\text { content }\end{array}$} & $5 \%$ & $\begin{array}{c}23.7 \pm 0.4 \\
(\mathrm{n}=8)\end{array}$ & $\begin{array}{c}23.6 \pm 1.1 \\
(\mathrm{n}=6)\end{array}$ & $\begin{array}{c}17.9 \pm 0.7 \\
(n=8)\end{array}$ & $\begin{array}{c}23.1 \pm 1.38 \\
(\mathrm{n}=4)^{\mathrm{k}}\end{array}$ \\
\hline & $35 \%$ & $\begin{array}{c}24.8 \pm 0.8 \\
(\mathrm{n}=8)\end{array}$ & $\begin{array}{c}23.3 \pm 0.5 \\
(\mathrm{n}=5)\end{array}$ & $\begin{array}{c}19.9 \pm 1.0 \\
(\mathrm{n}=8)\end{array}$ & $\begin{array}{c}21.2 \pm 1.0 \\
(\mathrm{n}=3)^{\mathrm{E}}\end{array}$ \\
\hline \multirow{2}{*}{$\begin{array}{l}\text { Triacylglycerol } \\
\text { concentration }\end{array}$} & $5 \%$ & $\begin{array}{c}0.082 \pm 0.004 \\
\quad(n=6)\end{array}$ & $\begin{array}{c}0.152 \pm 0.018 \\
(\mathrm{n}=6)^{\&}\end{array}$ & $\begin{array}{c}0.065 \pm 0.009 \\
(n=6)\end{array}$ & $\begin{array}{c}0.130 \pm 0.018 \\
(\mathrm{n}=6)^{\&}\end{array}$ \\
\hline & $35 \%$ & $\begin{array}{c}0.081 \pm 0.005 \\
\quad(\mathrm{n}=6)\end{array}$ & $\begin{array}{c}0.147 \pm 0.012 \\
\quad(\mathrm{n}=6)^{\&}\end{array}$ & $\begin{array}{c}0.068 \pm 0.006 \\
(n=6)\end{array}$ & $\begin{array}{c}0.137 \pm 0.027 \\
\quad(\mathrm{n}=6)^{\&}\end{array}$ \\
\hline \multirow{2}{*}{$\begin{array}{l}\text { Protein } \\
\text { concentration }\end{array}$} & $5 \%$ & $\begin{array}{c}5.7 \pm 0.3 \\
(\mathrm{n}=8)\end{array}$ & $\begin{array}{c}6.1 \pm 0.7 \\
(\mathrm{n}=6)\end{array}$ & $\begin{array}{c}8.3 \pm 0.2 \\
(\mathrm{n}=7)\end{array}$ & $\begin{array}{c}8.1 \pm 0.7 \\
(n=3)\end{array}$ \\
\hline & $35 \%$ & $\begin{array}{c}6.4 \pm 0.4 \\
(\mathrm{n}=8)\end{array}$ & $\begin{array}{c}6.1 \pm 0.3 \\
(n=5)\end{array}$ & $\begin{array}{c}8.7 \pm 0.3 \\
(n=7)\end{array}$ & $\begin{array}{c}8.3 \pm 0.7 \\
(n=4)\end{array}$ \\
\hline
\end{tabular}

\section{Discussion}

Plasma osmolality and chloride concentration found here in those two species of pufferfishes of the genus Sphoeroides were in agreement with previous studies using the same species (respectively $\sim 300$ mOsm. $\mathrm{kgH}_{2} \mathrm{O}^{-1}$, and $\sim 150 \mathrm{mM}$ ) (Prodocimo \& Freire, 2001, 2004, 2006). The results also fell within the range reported for other marine/estuarine teleosts (e.g., Maren et al., 1992; Claiborne et al., 1994; Zadunaisky et al., 1995; Zadunaisky, 1996; Jensen et al., 1998; Marshall et al., 1999). When facing salinity changes, plasma osmolality and chloride concentrations directly reflect the fishes capacity of extracellular fluid homeostasis. Alterations in these concentrations indicate disturbances in this function. Although both species are euryhaline and efficient osmoregulators, as expected for estuarine fishes, a decrease in plasma concentrations was noted upon short-term exposure of the fish to diluted seawater, confirming previous studies (Prodocimo \& Freire, 2004, 2006).

If there is extracellular fluid dilution, tissues endure os- motic challenge, and water influx is expected. Hematocrit and muscle tissue water are simple and useful techniques frequently employed to access osmotic challenges to the intracellular compartment (Plaut, 1998; Marshall et al., 1999; Claireaux \& Audet, 2000; Brown et al., 2001; Martinez-Álvarez et al., 2002; Prodocimo \& Freire, 2006). Hematocrit results obtained for $S$. testudineus and $S$. greeleyi were similar to those reported for other teleosts, of $\sim 25-30 \%$ (Plaut, 1998; Claireaux \& Audet, 2000; Brown et al., 2001; Martinez-Álvarez et al., 2002). Salinity reduction ( $5 \%$ ) lead to increased hematocrit in both pufferfishes, a result which may reflect red cell swelling, and the results in the $S$. greeleyi were higher than those of $S$. testudineus. As S. testudineus apparently has a higher capacity for tissue water content regulation regulation than $S$. greeleyi (Prodocimo \& Freire, 2006), its hematocrit increased, but not as much as in $S$. greeleyi. The opposite salinity challenge can lead to the same response. There are several reports of increased hematocrit upon exposure/acclimation of fishes to salinity increase. In this case, loss of extracellular water to the external medium would be the primary cause, although partially compensated by red cell shrinkage. However, eventually, regulatory volume increase of the red cells, coupled to an increase in red cell counts (long-term change) in order to cope with increasing demand for oxygen delivery following the increased metabolism would at the end lead to increased hematocrit (Plaut, 1998; Claireaux \& Audet, 2000; Brown et al., 2001; Martinez-Álvarez et al., 2002). In fact, in either direction, the response is variable, depending on the time of exposure, magnitude of the salinity challenge imposed, degree of change in plasma osmolality, and volume regulatory capacity of the red blood cells. Despite of the changes in hematocrit seen in the pufferfishes, their muscle cells apparently have a greater or faster capacity for tissue water regulation (as also in Prodocimo \& Freire, 2006), as in both species no differences in muscle tissue water content were noted, compatible with a previous report on the red grouper Epinephelus akaara and the black sea bream Mylio macrocephalus also submitted to dilute seawater (Woo \& Wu, 1982). The values of muscle water content $(\sim 80 \%)$ for both pufferfishes were similar to previous values reported for other euryhaline species (Feldmeth \& Waggoner, 1972; Plaut, 1998; Kelly \& Woo, 1999; Claireaux \& Audet, 2000; Brown et al., 2001; Martinez-Álvarez et al., 2002), as well as for the same species (Prodocimo \& Freire, 2006).

No mobilization of the metabolic substrates stored in the gills or kidney or in plasma glucose have been detected in $S$. testudineus and $S$. greeleyi upon this short-term exposure to salinity reduction. These results, coupled to the observation of no change in the total ATPase activity in both organs, means that branchial and renal metabolism remain stable upon this salinity challenge of short duration, a situation somewhat similar to what that these fishes could endure during ebb tide.

The lack of change in branchial total ATPase activity in both species when facing seawater dilution may either mean that this parameter does not adequately reflect the intensity of intermediary metabolism supplying ATP for this organ, or 
that the challenge imposed really does not mean a significant change in the energy budget of the gills. Actually it is possible that either to hypo-regulate in full-strength seawater, or to hyper-regulate in dilute seawater both require increased levels of branchial ATP supply ("U-shaped" curves, e.g. Stuenkel \& Hillyard, 1980; Jensen et al., 1998; Kelly et al., 1999; Imsland et al., 2003; Lin et al., 2004; Laiz-Carrión et al., 2005). Another possibility is that structural changes such as covering the apical pits of chloride cells turns off salt secretion, as reported for estuarine fish facing reduced salinities (Sakamoto et al., 2000; Daborn et al., 2001; Marshall, 2003), thus preventing the need to increase ATPase consumption and the activation of energy-consuming processes. In the kidney of $S$. greeleyi, total ATPase activity was reduced in dilute seawater when compared to full-strength seawater. It may well be that divalent ion secretion, one of the main responsibilities of the renal tubule when the fish is hypo-regulating in seawater, is turned off in dilute seawater (Jobling, 1995; Dantzler, 2003). This result is in agreement with that obtained in Sparus aurata, in which a direct relationship has been detected between renal $\mathrm{Na}^{+}, \mathrm{K}^{+}$-ATPase activity and salinity (Sangiao-Alvarellos et al., 2003). It should be pointed out that the marine euryhaline Dicentrarchus labrax displayed an opposite response, with increased renal ATPase activity when the fish were exposed to diluted seawater $(3 \%)$ and FW for 24 hours, due to the role of the renal tubules in salt absorption contributing to plasma hyper-regulation (Venturini et al., 1992). Still a different response may occur, in which the renal $\mathrm{Na}^{+}, \mathrm{K}^{+}$-ATPase is unaffected by salinity (McCormick et $a l ., 1989)$. This issue is worth of additional investigation, also clarifying the quantitative role played by the $\mathrm{Na}^{+}, \mathrm{K}^{+}$-ATPase with respect to total ATPase activity and tissue metabolism in fish gills and kidneys. Except for the renal activity in low salinity, $S$. greeleyi in general displayed higher total ATPase activities than $S$. testudineus. This finding may indicate that $S$. greeleyi, which prefers higher salinities (Prodocimo \& Freire, 2001, 2004, 2006), uses more ATP mainly in its gills either to hypo-regulate in full-strength seawater, or to hyper-regulate in dilute seawater.

Glycogen stored in branchial and renal tissues of the pufferfishes was very stable and unchanged due to exposure to reduced salinity. This may indicate that indeed fuel (glucose) may come from the main glycogen storage organ (the liver), being taken up by the gills, as previously suggested (Soengas et al., 1992; Vijayan et al., 1996; Laiz-Carrión et al., 2002; Sangiao-Alvarellos et al., 2003, 2005). Alternatively, the gills of the pufferfishes may provide the glucose they need, since they have glycogen levels $\sim 20-100$-fold higher than glycogen contents of the gills of Sparus auratus (Sangiao-Alvarellos et al., 2003, 2005; Laíz-Carrión et al., 2002, 2005), measured using the same methodology (Keppler \& Decker, 1974). Indeed, this mobilization of branchial glycogen has been recently demonstrated in the gills of the Mozambique tilapia (Tseng et al., 2007).

Plasma glucose was also maintained constant, and unchanged upon short-term exposure to dilute seawater. Interest- ingly, glycemia in the pufferfishes was very much lower $(\sim 20$ $\mathrm{mg} / \mathrm{dL}$, or $\sim 1 \mathrm{mM}$ ) than values reported either for freshwater or marine teleosts. This is consistent with the observation that pufferfish gills store lots of glycogen, thus not requiring the mobilization of liver glycogen, and blood transport of glucose. The freshwater rainbow trout displayed values in the range 36-144 mg/dL (Soengas et al., 1992; Figueroa et al., 2000), and the tilapia Oreochromis mossambicus $\sim 50-120 \mathrm{mg} / \mathrm{dL}$ (Nakano et al., 1998) or 36-108 mg/dL (Vijayan et al., 1996). Other marine teleosts such as the sea bass Dicentrarchus labrax ( $\sim 80 \mathrm{mg} / \mathrm{dL}$, Roche et al., 1989), the sea breams Sparus auratus $(80-90 \mathrm{mg} / \mathrm{dL}$, Mancera et al., 1993; 72-90 mg/dL, Sangiao-Alvarellos et al., 2005), Sparus sarba $(\sim 60-75 \mathrm{mg} /$ dL, Kelly \& Woo, 1999), and Chrysophrys major ( 30-45 mg/ dL, Woo \& Fung, 1981), the angelfish Pomacanthus imperator ( 10-50 mg/dL, Woo \& Chung, 1995), and the red grouper Epinephelus akaara $(\sim 30-50 \mathrm{mg} / \mathrm{dL}$, Woo \& Wu, 1982) had also values well above those measured for the pufferfishes. The marine teleosts Sparus sarba and S. aurata, submitted to salinities of 6-7\%o for 6-24 hours displayed increased plasma glucose levels (Mancera et al., 1993; Kelly \& Woo, 1999; Sangiao-Alvarellos et al., 2005). It may be that, being estuarine and more euryhaline, reduced salinities for a short period are not as stressful and energy demanding for the pufferfishes as it apparently is for less euryhaline marine teleosts.

Besides higher ATPase activity levels, S. greeleyi also displayed higher levels of triacylglycerol in its gills and kidney than $S$. testudineus, confirming a species difference in metabolism. The meaning of this difference cannot be explained by the present results; we cannot ascertain whether the rate of synthesis and storage is higher or the rate of degradation is lower in S. greeleyi than in S. testudineus. We cannot in fact infer that triacylglycerol stored in the gills and kidney would be a source of energy for the osmoregulation of these pufferfishes, as $S$. greeleyi displayed higher branchial ATPase activity than S. testudineus in diluted seawater. Plasma triacylglycerol have been shown to increase during osmoregulatory challenges imposed on Sparus auratus submitted to salinities of $6 \%$ or 55\% for 14 days, thus suggesting the use of these lipids as energy source for osmoregulation (Sangiao-Alvarellos et al., 2005). In accordance, the same species submitted to the isosmotic salinity of $12 \%$ also for 14 days displayed in no change in plasma triacylglycerol, in agreement with expected metabolism for osmoregulatory function (Sangiao-Alvarellos et al., 2003; Laiz-Carrión et al., 2005). Lipids as substrates to power ion transport in osmoregulatory organs should be the subject of future investigations.

The third metabolic substrate evaluated, protein, was also unchanged upon the salinity challenge imposed. This is an expected outcome, since the preferred metabolic substrates glycogen and lipids were also unchanged (Black \& Love, 1986). Protein concentration was assayed in the plasma and was also reported as stable upon salinity reduction in Sparus auratus (Laiz-Carrión et al., 2005; Sangiao-Alvarellos et al., 2003, 2005).

In conclusion, besides the ecological difference in salinity 
preference/tolerance, both species have confirmed previous results of an almost identical short-term osmoregulatory behaviour when facing salinity reduction, exception only for the higher hematocrit in S. greeleyi. In addition, they both did not display any clear sign of rapid metabolic substrate mobilization from stores in the osmoregulatory organs (gills and kidney). Euryhaline estuarine fish, when facing fast salinity changes, have been reported to rapidly activate several mechanisms to counteract changing gradients (Jacob \& Taylor, 1983; Marshall, 2003). Among these actions, they rapidly activate the $\mathrm{Na}^{+}, \mathrm{K}^{+}$-ATPase (Mancera \& McCormick, 2000), promote covering of the apical pits of the chloride cells (Sakamoto et al., 2000), and end up modulating unidirectional fluxes (Wood \& Laurent, 2003; Prodocimo et al., 2007). This fast pattern is strikingly in contrast with the slow responses observed in euryhaline migrating fish such as anguilids and salmonids (Madsen et al., 1996; Wilson et al., 2004), and apparently do not demand fast and significant depletion of metabolic stores in osmoregulatory organs.

\section{Acknowledgements}

The authors wish to acknowledge the immense help from Dr. Henry L. Spach of the Marine Studies Center (CEM) of the Universidade Federal do Paraná (UFPR) in collecting the fishes. Thanks also to the biologist Marcos P. T. Veiga for help with fish maintenance and in setting up the experiments. This study has been financed by CAPES (doctorate fellowship to VP), DAAD-German Academic Exchange Service (donation of laboratory equipment to $\mathrm{CAF}$ ). This work represents part of a Doctoral Dissertation by VP.

\section{Literature Cited}

Beyenbach, K .W. \& M. D. Baustian. 1989. Comparative physiology of the proximal tubule. From the perspective of aglomerular urine formation. Pp. 103-142. In: Kinne, R. K. H. (Ed). Structure and function of the kidney, v. 1. Comparative Physiology. Basel, Karger.

Beyenbach, K. W., C. A. Freire, R. K. H. Kinne \& E. Kinne-Saffran. 1993. Epithelial transport of magnesium in the kidney of fish. Mineral and Electrolyte Metabolism, 19: 241-249.

Black, D. \& R. M. Love. 1986. The sequential mobilisation and restoration of energy reserves in tissues of Atlantic cod during starvation and refeeding. Journal of Comparative Physiology, 156B: 469-479.

Bradford, M. M. 1976. A rapid sensitive method for the quantification of microgram quantities of protein utilizing the principle of protein-dye binding. Analytical Biochemistry, 72: 248-254.

Brown, J. A., W. M. Moore \& E. S. Quabius. 2001. Physiological effects of saline waters on zander. Journal of Fish Biology, 59: 1544-1555.

Claiborne, J. B., J. S. Walton \& D. Compton-Mccullough. 1994. Acid-base regulation, branchial transfers and renal output in a marine teleost fish (the long-horned sculpin Myoxocephalus octodecimspinosus) during exposure to low salinities. Journal of Experimental Biology, 193: 79-95.
Claireaux, G. \& C. Audet. 2000. Seasonal changes in the hypoosmoregulatory ability of brook charr: the role of environmental factors. Journal of Fish Biology, 56: 347-373.

Daborn, K., R. R. F. Cozzi \& W. S. Marshall. 2001. Dynamics of pavement cell-chloride cell interactions during abrupt salinity change in Fundulus heteroclitus. Journal of Experimental Biology, 204: 1889-1899.

Dantzler, W. H. 2003. Regulation of renal proximal and distal tubule transport: sodium, chloride and organic anions. Comparative Biochemistry and Physiology A, 136: 453-478.

Díaz, M., S. Cozzi, E. Almansa, M. Casariego, A. Bolaños, J. Cejas \& A. Lorenzo. 1998. Characterization of intestinal $\mathrm{Na}^{+}-\mathrm{K}^{+}-$ ATPase in the gilthead seabream (Sparus aurata L.). Evidence for a tissue-specific heterogeneity. Comparative Biochemistry and Physiolology B, 121: 65-76.

Evans, D. H., P. M. Piermarini \& W. T. W. Potts. 1999. Ionic transport in the fish gill epithelium. Journal of Experimental Zoology, 283: 641-652.

Evans, D. H., P. M. Piermarini \& K. P. Choe. 2005. The multifunctional fish gill: dominant site of gas exchange, osmoregulation, acid-base regulation, and excretion of nitrogenous waste. Physiological Reviews, 85: 97-177.

Feldmeth, C. R. \& J. P. Waggoner. 1972. Field measurements of tolerance to extreme hypersalinity in the California killifish, Fundulus parvipinnis. Copeia, 1972: 592-594.

Figueiredo, J. L. \& N. A. Menezes. 2000. Manual de peixes marinhos do sudeste do Brasil. VI Teleostei (5). Museu de Zoologia, São Paulo: Universidade de São Paulo.

Figueroa, R. I., R. Rodríguez-Sabarís, M. Aldegunde \& J. L. Soengas. 2000. Effects of food deprivation on $24 \mathrm{~h}$-changes in brain and liver carbohydrate and ketone body metabolism of rainbow trout. Journal Fish Biology, 57: 631-646.

Fiske, C. H. \& Y. Subbarow. 1925. The colorimetric determination of phophorus. Journal of Biological Chemistry, 66: 375-388.

Freire, C. A., E. Kinne-Saffran, K. W. Beyenbach \& R. K. H. Kinne. 1995. Na-D-glucose cotransport in renal brush-border membrane vesicles of an early teleost (Oncorhynchus mykiss). American Journal of Physiology, 269: R592-R602.

Hansen, H. J. M., M. H. Grosell \& P. Rosenkilde. 1999. Gill lipid metabolism and unidirectional $\mathrm{Na}^{+}$flux in the european eel $(\mathrm{An}$ guilla anguilla) after transfer to diluted media: the formation of wax alcohols as a primary response. Aquaculture, 177: 277-283.

Hentschel, H. \& K. Zierold. 1994. Morphology and element distribution of magnesium-secreting epitelium: the proximal tubule segment PII of dogfish, Scyliorhinus caniculus (L.). European Journal of Cell Biology, 63: 32-42.

Imsland, A. K., S. Gunnarsson, A. Foss \& S. O. Stefansson. 2003. Gill $\mathrm{Na}^{+}, \mathrm{K}^{+}$-ATPase activity, plasma chloride and osmolality in juvenile turbot (Scophthalmus maximus) reared at different temperatures and salinities. Aquaculture, 218: 671-683.

Jacob, W. F. \& M. H. Taylor. 1983. The time course of seawater acclimation in Fundulus heteroclitus L. Journal of Experimental Zoology, 228: 33-39.

Jensen, M. K., S. S. Madsen \& K. Kristiansen. 1998. Osmoregulation and salinity effects on the expression and activity of $\mathrm{Na}^{+}, \mathrm{K}^{+}$ATPase in the gills of european sea bass, Dicentrarchus labrax (1.). Journal of Experimental Zoology, 282: 290-300.

Jobling, M. 1995. Environmental Biology of Fishes. London, Chapman \& Hall, 455p.

Kelly, S. P. \& N. Y. S. Woo. 1999. The response of sea bream following abrupt hyposmotic exposure. Journal of Fish Biology, 55: 732-750. 
Kelly, S. P., I. N. K. Chow \& N. Y. S. Woo. 1999. Haloplasticity of balck seabream (Mylio macrocephalus): hypersaline to freshwater acclimation. Journal of Experimental Zoology, 283: 226-241.

Keppler, D. \& K. Decker. 1984. Glycogen. Pp. 11-17. In: Bergmeyer, H. U. (Ed.). Methods of Enzymatic Analysis. 3. ed. vol. VI Metabolites 1: Carbohydrates. Florida, Verlag Chemie.

Laiz-Carrión, R., S. Sangiao-Alvarellos, J. M. Guzmán, M. P. M. del Río, J. M. Míguez, J. L. Soengas \& J. M. Mancera. 2002. Energy metabolism in fish tissues related to osmoregulation and cortisol action. Fish Physiology and Biochemistry, 27: 179-188.

Laiz-Carrión, R., S. Sangiao-Alvarellos, J. M. Guzmán, M. P. M. del Río, J. L. Soengas \& J. M. Mancera. 2005. Growth performance of gilthead sea bream Sparus aurata in different osmotic conditions: implications for osmoregulation and energy metabolism. Aquaculture, 250: 849-861.

Lin, Y. M., R. S. Tsai \& T. H. Lee. 2004. Expression and distribution of Na,K-ATPase in gill and kidney of the spotted green pufferfish, Tetraodon nigroviridis, in response to salinity challenge. Comparative Biochemistry and Physiology A, 138: 287-295.

Madsen, S. S., B. K. Larsen \& F. B. Jensen. 1996. Effects of freshwater to seawater transfer on osmoregulation, acid-base balance and respiration in river migrating whitefish (Coregonus lavaretus). Journal of Comparative Physiology B, 166: 101-109.

Mancera, J. M. \& S. D. McCormick. 2000. Rapid activation of gill $\mathrm{Na}^{+}, \mathrm{K}^{+}$-ATPase in the euryhaline teleost Fundulus heteroclitus. Journal of Experimental Zoology, 287: 263-274.

Mancera, J. M., J. M. Perez-Figares \& P. Fernadez-Llebrez. 1993. Osmoregulatory responses to abrupt salinity changes in the euryhaline gilthead sea bream (Sparus aurata L.). Comparative Biochemistry and Physiology A, 106: 245-250.

Maren, T. H., A. Fine, E. R. Swenson \& D. Rothman. 1992. Renal acid-base in marine teleost, the long-horned sculpin Myoxocephalus octodecimspinosus. American Journal of Physiology, 263: F49-F55.

Marshall, W. S. 2003. Rapid regulation of $\mathrm{NaCl}$ secretion by estuarine teleost fish: coping strategies for short-duration freshwater exposures. Biochimica et Biophysica Acta, 1618: 95-105.

Marshall, W. S., T. R. Emberley, T. D. Singer, S. E. Bryson \& S. D. McCormick. 1999. Time course of salinity adaptation in a strongly euryhaline estuarine teleost, Fundulus heteroclitus: a multivariable approach. Journal of Experimental Biology, 202:1535-1544.

Martínez-Álvarez, R. M., M. C. Hidalgo, A. Domezain, A. E. Morales, M. García-Gallego \& A. Sanz. 2002. Physiological changes of sturgeon Acipenser naccarii caused by increasing environmental salinity. Journal of Experimental Biology, 205: 3699-3706.

McCormick, S. D., C. D. Moyes \& J. S. Ballantyne. 1989. Influence of salinity on the energetics of gill and kidney of Atlantic salmon (Salmo salar). Fish Physiology and Biochemistry, 6: 243-254.

Nakano, K., M. Tagawa, A. Takemura \& T. Hirano. 1998. Temporal changes in liver carbohydrate metabolism associated with seawater transfer in Oreochromis mossambicus. Comparative Biochemistry and Physiology B, 119: 721-728.

Perry, S. F. \& P. J. Walsh. 1989. Metabolism of isolated fish gill cells: contribution of epithelial chloride cells. Journal of Experimental Biology, 144: 507-520.

Plaut, I. 1998. Comparison of salinity tolerance and osmoregulation in two closely related species of blennies from different habitats. Fish Physiology and Biochemistry, 19:181-188.

Prodocimo, V. \& C. A. Freire. 2001. Ionic regulation in aglomerular tropical estuarine pufferfishes submitted to seawater dilution. Journal of Experimental Marine Biology and Ecology, 262: 243-253.
Prodocimo, V. \& C. A. Freire. 2004. Estuarine pufferfishes (Sphoeroides testudineus and $S$. greeleyi) submitted to seawater dilution during ebb tide: a field experiment. Marine and Freshwater Behaviour and Physiology, 37: 1-5.

Prodocimo, V. \& C. A. Freire. 2006. The $\mathrm{Na}^{+}, \mathrm{K}^{+}, 2 \mathrm{Cl}^{-}$cotransporter of estuarine pufferfishes (Sphoeroides testudineus and $S$. greeleyi) in hypo- and hyper-regulation of plasma osmolality. Comparative Biochemistry and Physiologyt C, 142: 347-355.

Prodocimo, V., F. Galvez, C. A. Freire \& C. M. Wood. 2007. Unidirectional $\mathrm{Na}^{+}$and $\mathrm{Ca}^{2+}$ fluxes in two euryhaline teleost fishes, Fundulus heteroclitus and Oncorhynchus mykiss, acutely submitted to a progressive salinity increase. Journal of Comparative Physiology B, 177: 519-528.

Roche, H., K. Chaar \& G. Peres. 1989. The effect of a gradual decrease in salinity on the significant constituents of tissue in the sea bass (Dicentrarchus labrax Pisces). Comparative Biochemistry and Physiology A, 93: 785-789.

Romão, S., C. A. Freire \& E. Fanta. 2001. Ionic regulation and $\mathrm{Na}^{+}, \mathrm{K}^{+}$-ATPase activity in gills and kidney of the Antarctic aglomerular cod icefish exposed to dilute sea water. Journal of Fish Biology, 59: 463-468.

Sakamoto, T., S. Yokota \& M. Ando. 2000. Rapid morphological oscillation of mitochondrion-rich cell in estuarine mudskipper following salinity changes. Journal of Experimental Zoology, 286: 666-669.

Sangiao-Alvarellos, S., R. Laiz-Carrión, J. M. Guzmán, M. P. M. del Río, J. M. Míguez, J. M. Mancera \& J. L. Soengas. 2003. Acclimation of $S$. aurata to various salinities alters energy metabolism of osmoregulatory and nonosmoregulatory organs. American Journal of Physiology, 285: R897-R907.

Sangiao-Alvarellos, S., F. J. Arjona, M. P. M. del Río, J. M. Míguez, J. M. Mancera \& J. L. Soengas. 2005. Time course of osmoregulatory and metabolic changes during osmotic acclimation in Sparus auratus. Journal of Experimental Biology, 208: 4291-4304.

Scott, G. R., J. G. Richards, B. Forbush, P. Isenring \& P. M. Schulte. 2004. Changes in gene expression in gills of the euryhaline killifish Fundulus heteroclitus after abrupt salinity transfer. American Journal of Physiology, 287: C300-C309.

Soengas, J. L., J. Fuentes, J. Otero, M. D. Andrés \& M. Aldegunde. 1992. Seasonal changes in carbohydrate metabolism in the rainbow trout (Oncorhynchus mykiss) and their relationship to changes in gill $\left(\mathrm{Na}^{+}-\mathrm{K}^{+}\right)$-ATPase activity. Aquaculture, 108: 369-380.

Stahl, W. L. \& D. G. Baskin. 1990. Histochemistry of ATPases. Journal of Histochemistry and Cytochemistry, 38: 1099-1122.

Stuenkel, E. L. \& S. D. Hillyard. 1980. Effects of temperature and salinity on gill $\mathrm{Na}^{+}-\mathrm{K}^{+}$ATPase activity in the pupfish, Cyprinodon salinus. Comparative Biochemistry Physiology A, 67: 179-182.

Tseng, Y. -C., C. -J. Huang, J. C. -H. Chang, W. -Y. Teng, O. Baba, M. -J. Fann \& P. -P. Hwang. 2007. Glycogen phosphorylase in glycogen-rich cells is involved in the energy supply for ion regulation in fish gill epithelia. American Journal of Physiology, 293: R482-R491.

Vendel, A. L., H. L. Spach, S. G. Lopes, \& C. Santos. 2002. Structure and dynamics of fish assemblages in a tidal creek environment. Brazilian Archives of Biology and Technology, 45: 365-373.

Venturini, G., E. Cataldi, G. Marino, P. Pucci, L. Garibaldi, P. Bronzi $\&$ S. Cataudella. 1992. Serum ions concentration and ATPase activity in gills, kidney and oesophagus of european sea bass (Dicentrarcus labrax, Pisces, Perciformes) during acclimation trials to fresh water. Comparative Biochemistry and Physiology A, 103: 451-454. 
Vijayan, M. M., J. D. Morgan, T. Sakamoto, E. G. Grau \& G. K. Iwama. 1996. Food-deprivation affects seawater acclimation in tilapia: hormonal and metabolic changes. Journal of Experimental Biology, 199: 2467-2475.

Wilson, J. M., J. C. Antunes, P. D. Bouça \& J. Coimbra. 2004. Osmoregulatory plasticity of the glass eel of Anguilla anguilla: freshwater entry and changes in branchial ion-transport protein expression. Canadian Journal of Fisheries and Aquatic Sciences, 61: 432-442.

Woo, N. Y. S. \& K. C. Chung. 1995. Tolerance of Pomacanthus imperator to hypoosmotic salinities: changes in body composition and hepatic enzyme activities. Journal of Fish Biology, 47: 70-81.

Woo, N. Y. S. \& A. C. Y. Fung. 1981. Studies on the biology of the red sea bream, Chrysophrys major - II. Salinity adaptation. Comparative Biochemistry and Physiology A, 69: 237-242.
Woo, N. Y. S. \& R. S. S. Wu. 1982. Metabolic and osmoregulatory changes in response to reduced salinities in the red grouper, Epinephelus akaara (Temminck \& Schlegel), and black sea bream, Mylio macrocephalus (Basilewsky). Journal of Experimental Marine Biology and Ecology, 65: 139-161.

Wood, C. M. \& P. Laurent. 2003. $\mathrm{Na}^{+}$versus $\mathrm{Cl}^{-}$transport in the intact killifish after rapid salinity transfer. Biochimica et Biophysica Acta, 1618: 106-119.

Zadunaisky, J. A. 1996. Chloride cells and osmoregulation. Kidney International, 49: 1563-1567.

Zadunaisky, J. A., S. Cardona, L. Au, D. M. Roberts, E. Fisher, B. Lowenstein \& E. J. Cragoe Jr. 1995. Chloride transport activation by osmolarity during rapid adaptation to high salinity of Fundulus heteroclitus. Journal of Membrane Biology, 143: 207-217.

Accepted August 2008 Published December 22, 2008 